\title{
Photodegradation of algal derived dissolved organic carbon*
}

\author{
David N. Thomas**, Rubén J. Lara
}

Alfred-Wegener-Institut für Polar- und Meeresforschung, Am Handelshafen 12, D-27570 Bremerhaven, Germany

\begin{abstract}
C}$-radiolabelled dissolved organic carbon $\left(\mathrm{DO}^{14} \mathrm{C}\right)$ produced in a Thalassiosira tumida culture was aged in the dark for $8 \mathrm{mo}$ and irradiated for $15 \mathrm{~h}$ at a UV intensity of $40 \mathrm{~W} \mathrm{~m}^{-2}$ at $350 \pm 20 \mathrm{~nm}$. Comparison with control bottles showed no evidence of $\mathrm{DO}^{14} \mathrm{C}$ decrease. Fractionation with $\mathrm{XAD}-2$ resin before and after irradiation indicated no changes in the humic fractions. This suggests that a pool of autochthonous marine DOC might be relatively resistant against natural UV radiation.
\end{abstract}

KEY WORDS: Dissolved organic carbon - Photodegradation . UV radiation

Recently there has been increased interest in the photodegradation of aquatic dissolved organic matter (DOM) (Kieber 1989, Mopper et al. 1991, De Haan 1993, Herndl et al. 1993). The oceans are one of the largest reservoirs of carbon as dissolved organic carbon (DOC), much of this in the form of humic substances, often considered to be biologically refractory. It is well established that photochemical degradation of humic substances by sunlight takes place, and may be an important source of substrates for microbial activity. This pathway has been proposed to be the rate-limiting step for removal of a large fraction of oceanic DOC, which might be enhanced with increasing flux of solar UV radiation due to depletion of stratospheric ozone (Kieber et al. 1989).

Photodegradation of terrestrially derived DOM resulted in a measurable destruction of DOC (De Haan 1993). During UV irradiation of Aldrich humic acid, DOC decreased by about $50 \%$ over 20 h (Allard et al.

\footnotetext{
- This is publication 834 of the Alfred-Wegener-Institut für Polar- und Meeresforschung

* Present address: Institut für Chemie und Biologie des Meeres, Universität Oldenburg, D-26111 Oldenburg, Germany
}

1994). However, in general, such terrestrial organic material has a greater aromaticity than marine DOM, and may be more prone to photodegradation, as discussed by Moran \& Hodson (1994). Moran \& Hodson have suggested that this might help explain the apparent discrepancy between the refractory nature of terrestrially derived humics and their relatively low abundance compared with autochthonous marine DOM. Thus, since oceanic DOM is mainly phytoplankton derived, it seems appropriate to consider the effect of photodegradation processes on algal-produced organic matter.

In a long-term experiment we obtained ${ }^{14} \mathrm{C}$-radiolabeled DOC, produced in an antarctic marine diatom (Thalassiosira tumida) culture grown at $0^{\circ} \mathrm{C}$ in seawater enriched with $\mathrm{NaH}^{14} \mathrm{CO}_{3}$. The culture was grown in continuous light, and was placed in the dark after $18 \mathrm{~d}$, when it reached the stationary phase (determined by a levelling off in the assimilation of radiolabel into the particulate fraction). The $\mathrm{DO}^{14} \mathrm{C}$ produced was aged in the dark for $8 \mathrm{mo}$ at this temperature, during which time it was aerated gently. This was long enough to ensure that bacterial decomposition of readily decomposable organic matter had taken place. The chemical characteristics of this DOC have been described (Lara \& Thomas 1994a, b). Triplicate $50 \mathrm{ml}$ samples containing $\mathrm{DO}^{14} \mathrm{C}(0.2 \mu \mathrm{M}$ filtered) were incubated in quartz flasks with a large headspace for $15 \mathrm{~h}$ at a UV intensity of $40 \mathrm{~W} \mathrm{~m}^{-2}$ in the wavelength range 300 to $400 \mathrm{~nm}$ (most light was emitted at $350 \pm 20 \mathrm{~nm}$ ). This corresponds to the average daily sunlight intensity in the same range as that at a latitude of $40^{\circ}$ (R. Weller pers. comm.). Control flasks were kept in the dark. At hourly intervals $2 \mathrm{ml}$ were removed from irradiated and control flasks, acidified, left for $24 \mathrm{~h}$, and radioactivity measured by scintillation counting. Any complete DOC oxidation would produce ${ }^{14} \mathrm{CO}_{2}$ released upon acidification. Upon comparison 


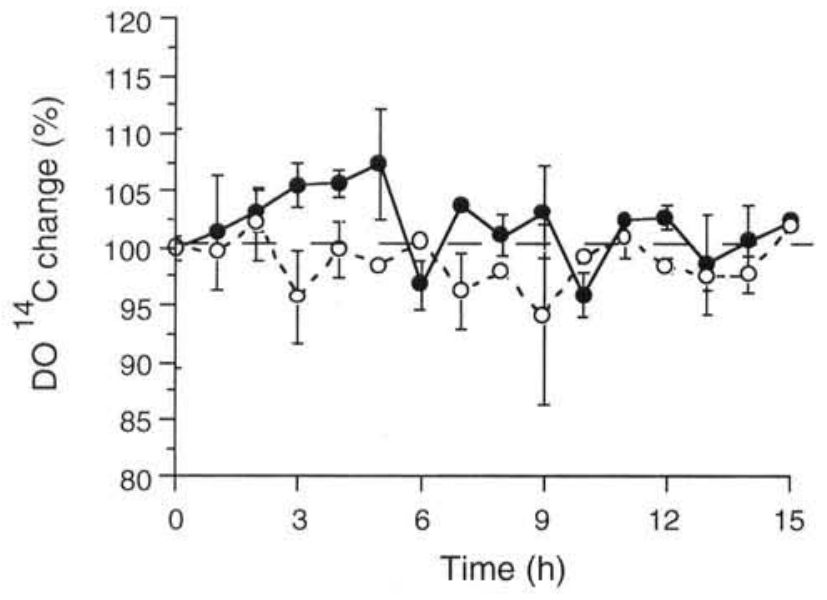

Fig. 1. Mean $( \pm \mathrm{SD})$ percentage changes in $\mathrm{DO}^{14} \mathrm{C}$, calculated using time $=0$ as $100 \%$. (•) Irradiated at $40 \mathrm{~W} \mathrm{~m}^{-2}$ essentially emitted at $350 \pm 20 \mathrm{~nm}$. (ㅇ) Control samples kept in the dark

with control bottles, there was no evidence of DOC decrease (Fig. 1).

In order to determine whether UV treatment resulted in changes in the humic substance pool, $\mathrm{DO}^{14} \mathrm{C}$ was fractionated before and after irradiation with XAD-2 resin as described in Lara \& Thomas (1994a). There were no changes in the proportions of the humic fractions, whose hydrophobic acid and neutral components accounted for 20 and $10 \%$ of $\mathrm{DO}^{14} \mathrm{C}_{\text {, }}$ respectively.

Since proteinaceous matter is thought to be involved in the formation of refractory compounds (Ishiwatari 1992 ) it is likely that their disruption will release free amino acids, as well as ammonia, carbonyls and carboxylic acids. HPLC analysis showed that dissolved free amino acids did not change significantly during

This note was submitted to the editor irradiation (U. Hubberten pers. comm.). Although only these compounds were measured, their constancy further suggests the stable character of this DOM.

These results are an indication that the pool of autochthonous marine DOM might not be so readily photo-oxidised. This would caution against a general extrapolation of results from photodegradation experiments with terrestrially derived DOM to oceanic carbon budgets.

\section{LITERATURE CITED}

Allard, B., Borén, H., Pettersson, C., Zhang, G. (1994). Degradation of humic substances by UV irradiation. Environ. Int. 20: $97-101$

De Haan, H. (1993). Solar UV-light penetration and photodegradation of humic substances in peaty lake water. Limnol. Oceanogr. 38: 1072-1076

Herndl, G. J., Müller-Niklas, G., Frick, J. (1993). Major role of ultraviolet-B in controlling bacterial plankton growth in the surface layer of the ocean. Nature 361: 717-718

Ishiwatari, R. (1992). Macromolecular material (humic substance) in the water column and sediments. Mar. Chem. 39: 151-166

Kieber, D. J., McDaniel, J., Mopper, K. (1989). Photochemical source of biological substrates in sea water: implications for carbon cycling. Nature 341: 637-639

Lara, R. J., Thomas, D. N. (1994a). XAD-fractionation of 'new' dissolved organic matter: is the hydrophobic fraction seriously underestimated? Mar. Chem. 47:93-96

Lara, R. J., Thomas D. N. (1994b). Isolation of marine dissolved organic matter: evaluation of sequential combinations of XAD resins 2, 4 and 7. Analyt. Chem. 66: 2417-2419

Mopper, K., Zhou, X., Kieber, R. J., Kieber, D. J., Sikorski, R. J., Jones, R. D. (1991). Photochemical degradation of dissolved organic carbon and its impact on the oceanic carbon cycle. Nature 353: 60-62

Moran, M. A., Hodson, R. E. (1994). Support of bacterioplankton production by dissolved humic substances from three marine environments. Mar. Ecol. Prog. Ser. 110: 241-247

Manuscript first received: October 7, 1994

Revised version accepted: November 9, 1994 